\title{
Kritički osvrt na konceptualne i metodološke probleme u istraživanjima evolucije socijalne kognicije na primjeru kooperativnoga rješavanja problema
}

\author{
Ljerka Ostojić \\ Institute for Globally Distributed Open Research and Education (IGDORE), \\ Rijeka, Hrvatska
}

\begin{abstract}
Sažetak
Jedno je od glavnih istraživačkih područja u socijalnoj kogniciji životinja kooperativno rješavanje problema, tj. kognicija kod međusobne suradnje životinja. Smatra se da je socijalna kognicija evoluirala zbog zahtjeva koje donosi život u grupama i često se drži adaptacijom za takav život. Analiza socijalnoga učenja, drugoga istraživačkog područja unutar socijalne kognicije, pokazala je da je ta pretpostavka u literaturi prouzročila dva problema. Prvo, postoji pristranost prema testiranju socijalnih vrsta, i drugo, postoji a priori pretpostavka da je socijalno učenje kvalitativno drugačije od individualnoga. Ta dva problema nisu nužno ograničena na socijalno učenje, nego mogu biti prisutna i u drugim poljima unutar istraživanja socijalne kognicije. Primjena slične analize na kooperativno rješavanje problema ukazuje da i u tome području postoje oba problema. Prvo, empirijska se istraživanja provode ponajprije na vrstama koje su socijalne i na onima koje pokazuju kooperativna ponašanja u divljini. Drugo, pretpostavka da se kooperativno rješavanje problema temelji na specifično socijalnim kognitivnim sposobnostima implicirana je u velikome dijelu literature. Moguće je da je to rezultat miješanja različitih komponenti unutar kognitivnoga procesa: koja je informacija potrebna za uspješnu kooperaciju i kako se ta informacija stječe. Dok prva komponenta mora uključivati informaciju o drugome pojedincu, ne postoji indikacija da se druga komponenta mora razlikovati od već poznatih, općenamjenskih mehanizama. Ta dva problema sprečavaju sistematsko ispitivanje razlika između vrsta i ometaju istraživanje evolucije kooperativnoga rješavanja problema.
\end{abstract}

Ključne riječi: evolucija, socijalna kognicija, kooperacija, kooperativno rješavanje problema, učenje, životinje

Ljerka Ostojić, Ede Jardasa 35, 51000 Rijeka, Hrvatska. E-pošta: ljerka.ostojic@igdore.org

Zahvale:

Hvala Edwardu Leggu za kodiranje podataka, Benu Farraru za komentare, Krešimiru Đuđeviću za komentare i pomoć pri prijevodu te Igoru Bajšanskom za pomoć pri prijevodu terminologije. 


\section{Uvod}

U polju komparativne psihologije i bihevioralne ekologije socijalna kognicija označava sposobnost fleksibilne prilagodbe (adaptacije) na izazove života u socijalnome okruženju (Shettleworth, 1998). Pretpostavlja se da je socijalnost predstavljala selekcijski pritisak u evoluciji socijalne kognicije (Byrne i Whiten, 1988; Dunbar, 1992, 1998; Humphrey, 1976; Jolly, 1966; Schultz i Dunbar, 2007; Whiten i Byrne, 1997). Kooperativno rješavanje problema jedno je od glavnih područja unutar socijalne kognicije koje zanima i psihologe i ekologe, a bavi se kognitivnim sposobnostima koje omogućuju životinjama da surađuju. Ovaj pregledni rad obuhvaća temu kooperativnoga rješavanja problema, međutim, cilj mu nije pružiti sistematski pregled različitih istraživanja ili njihovih rezultata, već istaknuti sveobuhvatne probleme koji se pojavljuju u literaturi o kooperativnome rješavanju problema. Dosad su ti problemi bili identificirani u području socijalnoga učenja. Rad je podijeljen u dva dijela. Prvi dio obuhvaća kratki uvod u socijalnu kogniciju i raspravu o relevantnim problemima u literaturi o socijalnome učenju. Drugi dio rada dokumentira glavne načine testiranja kooperativnoga rješavanja problema kod životinja. Slijedi diskusija o tome u kojoj mjeri literatura o kooperativnome rješavanju problema pokazuje iste probleme kao i literatura o socijalnome učenju. Naposljetku, rad ukazuje koje su implikacije tih problema za istraživanja evolucije kognitivnih sposobnosti koje omogućuju životinjama da međusobno surađuju.

\section{Socijalna kognicija i njena evolucija}

Socijalna kognicija koristi se kao opći pojam za kognitivne sposobnosti koje omogućuju životinjama fleksibilno reagiranje i obrađivanje informacija iz svoga socijalnog okruženja. Te kognitivne sposobnosti obuhvaćaju individualno prepoznavanje drugih pojedinaca, praćenje lokacije, prepoznavanje ponašanja drugih pojedinaca i njihovih uspjeha u pronalaženju hrane, klasifikaciju članova grupe prema apstraktnim pojmovima (npr. prema srodstvu), praćenje odnosa između drugih pojedinaca i praćenje tko je što učinio komu (Cheney i Seyfarth, 1990; Shettleworth, 1998). Tu vrstu informacija životinje zatim koriste za prilagodbu svoga ponašanja i predviđanje ili manipulaciju ponašanja drugih pojedinaca. Socijalna je kognicija, dakle, pojam koji opisuje kognitivne sposobnosti kojima se životinje koriste kada je uključen još jedan socijalni podražaj. Taj socijalni podražaj može biti prisutnost druge životinje ili neki oblik njezine reprezentacije, npr. vokalizacija životinje.

Hipoteze o evoluciji kognicije primarno predlažu da su nepredvidljivost $\mathrm{i}$ varijabilnost života u kompleksnome socijalnom okruženju predstavljali selekcijski pritisak za evoluciju socijalne kognicije (Byrne i Whiten, 1988; Dunbar, 1992, 1998; Humphrey, 1976; Jolly, 1966; Whiten i Byrne, 1997). Smatra se da je ili kvantiteta ili kvaliteta socijalnih interakcija ključni čimbenik koji pridonosi kompleksnosti 
socijalnoga okruženja, ovisno o vrsti i razredu životinje (Ashton i sur., 2018; Boucherie i sur., 2019; Dunbar, 1992; Emery i Clayton, 2004; Emery i sur., 2007; Fraser i Bugnyar 2010; Shultz i Dunbar, 2007).

\section{Sveobuhvatni problemi u istraživanju socijalne kognicije}

Tradicionalno su psiholozi istraživali opće kognitivne mehanizme poput učenja ili pamćenja. Za razliku od psihologa, bihevioralni ekolozi primarno su istraživali adaptivnu vrijednost pojedinih ponašanja koje životinje pokazuju u divljini, npr. kako sposobnost prepoznavanja pojedinaca unutar njihove grupe utječe na sposobnost opstanka neke vrste. Velik se broj kognitivnih sposobnosti koje su danas predmet istraživanja u komparativnoj psihologiji temelji na ponašanjima koje bihevioralni ekolozi proučavaju već dugo vremena (McAuliffe i Thornton, 2015). Primjeri su kooperacija (uključujući različite oblike kooperacije, npr. altruizam i reciprocitet; Dugatkin, 1997, 2002), socijalno učenje (Hoppitt i Laland, 2008), individualno prepoznavanje i podučavanje (Thornton i Raihani, 2008). Na sva ta ponašanja nailazimo kod socijalnih vrsta. Adaptacija se često smatra glavnim mehanizmom za pojavu neke osobine (Gould i Lewontin, 1979). Stoga postoji često implicitna - pretpostavka da kognicija na kojoj se temelje socijalna ponašanja uvijek nužno predstavlja adaptaciju na život u grupama (Heyes, 2012b; Klopfer, 1959; McAuliffe i Thornton, 2015). Glavni je problem te pretpostavke da redovito ostaje neispitana (Almor, 2003).

Implikacije koje pretpostavka adaptivnosti može imati na istraživanje socijalne kognicije prikazane su na slučaju istraživanja socijalnoga učenja. Konkretno, Heyes (2012b) i Sterelny (2009) identificirali su dva sveobuhvatna problema koji se protežu kroz literaturu o socijalnome učenju. Prvi je problem pristranost prema izboru životinjske vrste koju istraživači testiraju. Drugi je problem odvajanje socijalne od nesocijalne kognicije. Kad je riječ o istraživanjima o socijalnome učenju, prvi se problem temelji na pristranosti prema testiranju socijalnih vrsta. Heyes (2012b) je ukazala da su, iako postoje izvještaji o socijalnome učenju kod velikoga raspona vrsta, u vrijeme objavljivanja te publikacije postojala samo dva istraživanja o socijalnome učenju kod solitarnih vrsta: jedno kod crvenonoge kornjače (Chelonoidis carbonarius; Wilkinson i sur., 2010) i jedno kod hobotnice (Octopus vulgaris; Fiorito i Scotto, 1992). Usto, Lefebvre i suradnici (1996) direktno su usporedili dvije vrste ptica iz porodice goluba (Combidae), jednu socijalnu (Columba livia) i jednu teritorijalnu (Zenaida aurita). Kasnije je objavljeno više istraživanja o socijalnome učenju nesocijalnih vrsta, ponajprije kod gmazova (Kar i sur., 2017; Kis i sur., 2015; Noble i sur., 2014). Doody i suradnici (2013) tvrde da bi svrstavanje gmazova u nesocijalne vrste moglo biti netočno. Međutim, za ovaj je pregledni rad relevantno da autori predlažu da je upravo percepcija gmazova kao nesocijalnih životinja uzrok tomu što su dugo bili isključeni iz istraživanja socijalne kognicije. Glavni je problem takve pristranosti u literaturi jačanje pretpostavke da je socijalno učenje adaptacija na život u grupama. Kada se rutinski ne provode istraživanja s 
vrstama koje su manje socijalne ili uopće nisu socijalne, onda se hipoteza adaptacije ne može testirati. $U$ isto vrijeme takva pristranost u literaturi ometa donošenje zaključaka o ulozi socijalnih selekcijskih pritisaka u evoluciji kognicije.

Drugi je problem tendencija tretiranja socijalnoga učenja kao kvalitativno različitoga od učenja kod kojega nije uključena druga životinja, tj. od individualnoga učenja (Heyes, 1994, 2012b). Sterelny (2009) i Heyes (1994, 2012a, 2012b) pokušali su razjasniti različite komponente kognitivnoga procesa unutar socijalnoga učenja. Autori su identificirali koje bi od tih komponentni mogle biti jedinstveno socijalne prirode. Analiza kognitivnoga procesa prema Heyes $(1994,2012 b)$ uključuje tri komponente. Prvo, ulazni mehanizam (engl. input mechanism) prikazuje kognitivnomu sustavu vanjske podražaje. Mehanizmom stjecanja (engl. acquiring mechanism) kognitivni sustav stječe i oblikuje sadržaj reprezentacije. Nakraju, taj sadržaj određuje ponašajni odgovor ili ponašajni ishod (engl. behavioural output). Kako bi identificirao relevantne vanjske podražaje iz svih podražaja koji su prisutni u okruženju, kognitivni sustav mora biti opremljen prikladnim procesima percepcije, pozornosti i motivacije. S obzirom na to da socijalno i individualno učenje pozitivno koreliraju i na razini vrste (Lefebvre i Giraldeau, 1996; Reader i sur., 2011; Reader i Laland, 2002) i na individualnoj razini (zebraste zebe [Taeniopygia guttata]; Boogert i sur., 2008; Bouchard i sur., 2007), Heyes (2012b) predlaže da je mehanizam stjecanja informacija kod socijalnoga učenja isti kao i kod individualnoga učenja te da je vrlo vjerojatno riječ o asocijativnome učenju. Kod socijalnoga učenja jedinstveno je socijalne prirode ulazni mehanizam jer životinja opaža podražaj o kojemu uči u prisutnosti i ponašanjem drugoga pojedinca (Heyes, 2012b; engl. social input representation: Almor, 2003; engl. social channel: Sterelny, 2009). Na ulazni mehanizam mogu utjecati procesi percepcije (npr. perceptivni sustav koji omogućuje detaljno razlikovanje pojedinaca; Byrne i Bates, 2007), sustav pozornosti (Tomasello, 1995; na primjer, selektivna pozornost prema važnim dijelovima tijela drugih pojedinaca; Byrne i Bates, 2007, Marzluff i sur., 2010) i sustav motivacije.

Heyes (2012b) nadalje predlaže mogućnost da ti ulazni mehanizmi predstavljaju adaptaciju na život u socijalnim grupama i da mogu biti rezultat ili procesa filogeneze ili procesa ontogeneze (Behrens i sur., 2008; Carlier i Lefebvre, 1997; Dolman i sur., 1996; Dyer i sur., 2005; Galef, 1981; Klein i sur., 2008; Miller i Dollard, 1941). S druge strane, kognitivni mehanizam (tj. mehanizam stjecanja) vjerojatno ne predstavlja kognitivnu adaptaciju za socijalni život, nego je specijalan slučaj u kojemu su generalne sposobnosti učenja primijenjene na socijalni kontekst. Izvještaji o socijalnome učenju kod vrsta koje se ne smatraju socijalnima u skladu su s tom hipotezom. Međutim, uzevši u obzir da u literaturi o socijalnome učenju dominiraju testiranja socijalnih vrsta, ta literatura vjerojatno (još) nije reprezentativna glede stvarne distribucije socijalnoga učenja među vrstama.

Socijalno učenje vjerojatno nije jedino područje unutar istraživanja socijalne kognicije u kojemu su prisutna ta dva problema. To se može argumentirati analogijom jer su hipoteze o evoluciji kognicije i pretpostavka o njezinoj adaptaciji 
prisutne u cijelome području istraživanja socijalne kognicije. Zato se u sljedećeme dijelu ovoga preglednog rada primjenjuje slična analiza na istraživanja o kooperativnome rješavanju problema. Cilj je ove analize utvrditi $u$ kojemu je stupnju to područje zahvaćeno istim problemima.

\section{Kooperativno rješavanje problema}

Kooperativno rješavanje problema odnosi se na situaciju u kojoj jedna životinja ne može sama riješiti problem (Chalmeau i Gallo, 1995; Schuster i Perelberg, 2004) pa uspjeh ovisi o zajedničkome radu dviju životinja (ili više životinja; Heaney i sur., 2017; Visalberghi, 1997). Stoga pojam kooperativnoga rješavanja problema opisuje što se događa na razini ponašanja, kao i kod socijalnoga učenja (prema Heyes, 2012b).

Međutim, to je ujedno i glavni pojam koji se koristi kad su u pitanju kognitivne sposobnosti na kojima se temelji kooperacija kod životinja. Pojam kooperacije obično se rabi u puno širemu smislu i obuhvaća istraživanja kooperacije (uključujući mutualizam, reciprocitet, altruizam) kao evolucijski stabilne strategije. Prema tome, ovaj pregledni rad koristit će pojam kooperativnoga rješavanja problema kao i većina literature, kako bi se ukazalo na bilo koju razinu kognicije koja je uključena u situaciju u kojoj životinje zajedno izvode neku radnju. Kooperativna se ponašanja kod vrsta koje žive u kompleksnim socijalnim sustavima smatraju kognitivno kompleksnima jer se možda temelje na sposobnosti povezivanja vlastitih radnji s ponašanjem drugih pripadnika vrste. Opažanja lova kod čimpanzi (Pan troglodytes) bila su temelj prve definicije kooperativnoga rješavanja problema (Boesch i Boesch, 1989). Prema toj se definiciji mogu specificirati četiri razine sve veće organizacije između životinja u nekoj grupnoj aktivnosti. Na prvoj razini životinje izvode slične radnje usmjerene prema istome objektu bez ikakve povezanosti između radnji $u$ vremenu i prostoru (sličnost). Na drugoj razini postoji povezanost između tih radnji $\mathrm{u}$ vremenu (sinkronija), dok na trećoj razini postoji povezanost između radnji i u vremenu i u prostoru (koordinacija). Na četvrtoj i najvišoj razini životinje izvode komplementarne radnje usmjerene prema istome objektu (kolaboracija). S obzirom na to da je koordinacija prva razina na kojoj životinje moraju prilagoditi svoje radnje ponašanju partnera u prostoru i vremenu, upravo je to tema većine istraživanja kognitivne kompleksnosti kooperacije među životinjama. Stoga ta istraživanja primarno ispituju mogu li životinje koordinirati svoje radnje s ponašanjem svoga partnera. Različiti istraživači koriste različitu terminologiju kako bi opisali kada neko ponašanje zadovoljava kriterije za koordinaciju u testu kooperativnoga rješavanja problema. Međutim, gotovo svim je opisima zajednički zahtjev da životinje moraju spojiti način na koji se zadatak mora riješiti s potrebom usklađivanja svoga ponašanja s ponašanjem svoga partnera. Prema Chalmeau i Gallo (1995) ti se čimbenici mogu odnositi na različite sposobnosti, tj. na individualnu kompetenciju ili kauzalnost zadatka (Jelbert i sur., 2015) i na socijalnu kompetenciju ili potrebu za rad s 
partnerom (Visalberghi i sur., 2000). Uspješno rješavanje testa zahtijeva integraciju tih sposobnosti.

\section{Istraživanja kooperativnoga rješavanja problema kod životinja}

U većini se istraživanja kooperativnoga rješavanja problema pokušava testirati razinu koordinacije između partnera tijekom rješavanja zadatka (prema Boesch i Boesch, 1989). Alternativni pravac istraživanja ispituje biraju li životinje svoga partnera za rješavanje problema i na temelju čega to čine (Asakawa-Haas i sur., 2016; Melis i sur., 2006a; Molesti i Majolo, 2016; Scheid i Noë, 2010; Suchak i sur., 2014), a to može uključivati i pitanja o razini kognicije uključene u odabir partnera (Massen i sur., 2015). Postoji širok konsenzus o „,najboljemu“ bihevioralnom testu (AlbiachSerrano, 2015) koji se u isto vrijeme može koristiti s većinom vrsta. Taj je test poznat kao zadatak „slobodnoga konopa“ (engl. „loose string” task). Originalni nacrt potječe od Crawford (1937), a naknadno su ga adaptirali Hirata i Fuwa (2007). U tome testu u fazi treninga životinje pojedinačno uče da se platforma na kojoj se nalazi hrana može dosegnuti povlačenjem obaju krajeva jednoga konopa. Konop je slobodan jer je, na primjer, provučen kroz prsten na platformi, tako da povlačenje jednoga kraja dovodi do pomicanja konopa, ali ne i platforme. U sljedećoj fazi testiranja krajevi konopa postavljeni su dovoljno daleko jedan od drugoga tako da životinja ne može samostalno povući oba kraja. Hrana se može dosegnuti samo ako dvije životinje istovremeno povuku svaka jedan kraj konopa. S obzirom na to da je konop slobodan, samostalno je povlačenje rizično. Mogu li životinje uspješno riješiti zadatak i nakon što je jedna od njih sama povukla konop, ovisi o dužini konopa koja je dostupna svakomu pojedincu te o načinu povlačenja. Postoji nekoliko razloga zbog kojih test „,slobodnoga konopa“ ima status standardnoga testa kooperativnoga rješavanja problema. Jedan je razlog postojanje relativno visokoga konsenzusa - što je neobično za komparativnu psihologiju - da je tim testom moguće (izuzevši eventualne probleme sa statističkim zaključcima) razlikovati životinje koje koordiniraju svoje radnje kako bi riješile zadatak od onih koje to ne mogu (v. Jaakolla i sur., 2018 za jedno neslaganje s tom tvrdnjom). Test omogućuje velik raspon manipulacija kojima se može ispitati kompleksnost kognitivne sposobnosti na kojoj se temelji rješavanje toga zadatka. Istovremeno, test je mehanički jednostavan, tako da je kauzalna struktura zadatka jasna, što potencijalno smanjuje kognitivno opterećenje i povećava ekološku valjanost (Albiach-Serrano, 2015; Massen i sur., 2019). Zbog svoje se jednostavnosti test može lako adaptirati za različite životinjske vrste. Iako se test najčešće rabi u situacijama u kojima su prisutne dvije životinje (ili tri, u ispitivanjima odabira partnera; Scheid i Noë, 2010), može se koristiti i u grupnoj situaciji (Asakawa-Haas i sur., 2017; Massen i sur., 2015; Schmelz i sur., 2017) i s divljim populacijama (Kaigaishi i sur., 2019; Molesti i Majolo, 2016).

Unatoč konsenzusu o korisnosti testa „slobodnoga konopa“ koji postoji u literaturi, prisutno je nekoliko razlika u načinu na koji se test izvodi. Jedna se takva razlika odnosi na trening koji životinje prolaze na početku ispitivanja. Većina 
istraživanja uključuje fazu treninga u kojoj se oba kraja konopa postavljaju tako da se udaljenost između njih postupno povećava ne bi li se olakšalo učenje da treba povući oba kraja u isto vrijeme (de Montaigu i sur., 2019; Heaney i sur., 2017; Marshall-Pescini i sur., 2017; Ostojić i Clayton, 2014; Seed i sur., 2008). Istovremeno, samo malen broj istraživanja uključuje i transfer-test na kraju treninga da bi se ispitalo jesu li životinje zaista naučile da trebaju povući oba kraja (Ostojić i Clayton, 2014). U drugim istraživanjima životinje prolaze trening u kojemu mogu dosegnuti hranu tako da povuku jedan kraj konopa jer je drugi kraj čvrsto pričvršćen za platformu (Kaigashi i sur., 2019; Molesti i Majolo, 2016; Plotnik i sur., 2011; Scheid i Noë, 2010; Schmelz i sur., 2017). U tim istraživanjima relevantnost treninga nije jasna jer životinje moraju naučiti da treba povući oba kraja konopa tijekom faze testiranja, što trening čini donekle suvišnim. Taj postupak može i ometati jasnu interpretaciju rezultata $u$ fazi testiranja jer životinje mogu riješiti zadatak tako da svaka odvojeno koristi iste strategije kao i u fazi treninga (Seed i Jensen, 2011). Mali broj istraživanja uključuje postupak u kojemu nema faze treninga pa se životinje prvi put susreću sa zadatkom u fazi testiranja (de Montaigu i sur., 2019; Marshall-Pescini i sur., 2017; Yamamoto i sur., 2019). Na taj se način ispituje mogu li životinje zajedno naučiti kako se rješava zadatak. Ta se varijanta testa ne koristi često, međutim, mogla bi biti korisna pri ispitivanjima kako dolazi do kooperativnoga rješavanja problema u prirodnijoj okolini (Fruteau i sur., 2013).

Postoji još jedna razlika između istraživanja, a odnosi se na različite uvjete kojima se ispituje kognitivna sposobnost na kojoj se temelji rješavanje testa (Albiach-Serrano, 2015). Najčešće korišten uvjet za testiranje koordinacije u vremenu i prostoru takozvani je test kašnjenja. U tome testu jedan od partnera kasni u svome pristupu konopu, tako da drugi partner mora odgoditi radnju povlačenja konopa, dok partner koji kasni nije u mogućnosti to učiniti. Uspješno rješavanje toga zadatka stoga ne ovisi samo o prepoznavanju potrebe za partnerom nego i o sposobnosti životinje da inhibira reakciju koja je ranije dovela do uspjeha u testu, a to je u ovome slučaju povlačenje konopa. Stoga test kašnjenja nije samo praktičan uvjet za testiranje koordinacije nego ujedno ističe važnost izvršnih funkcija za kooperaciju (Baker i Rachlin, 2002; Brosnan i sur., 2010; Fehr i Fischbacher, 2004; Melis i Semmann, 2010; Stevens i sur., 2005; Stevens i Hauser, 2004). Iako velik broj istraživanja kooperativnoga rješavanja problema koristi taj uvjet, postoji varijacija u načinu na koji se usporava partner, tj. u načinu na koji mu se odgađa pristup konopu. U većini istraživanja eksperimentator (ili pomoćnik) direktno otpušta partnera ili to čini nekakav mehanizam koji otvara vrata nakon prethodno utvrđenoga vremena (de Montaigu i sur., 2019; Heaney i sur., 2017; Marshall-Pescini i sur., 2017; Massen i sur., 2010; Péron i sur., 2011; Plotnik i sur., 2011; Seed i sur., 2008). Jedan je mogući problem te metode da životinje možda ne mogu procijeniti zašto partner kasni ili kada će partner dobiti pristup konopu. Samo mali broj istraživanja uključuje način odgađanja pristupa jednoga od partnera koristeći neku od metoda koje imaju višu razinu ekološke valjanosti, npr. labirint kroz koji partner mora proći (Ostojić i Clayton, 2014) ili manipulaciju lokacije aparata tako da jednoj 
životinji treba više vremena da stigne do njega (Schmelz i sur., 2017). Takve metode mogle bi životinji olakšati inhibiciju reakcije jer cijelo vrijeme može pratiti partnera i njegov napredak (Ostojić i Clayton, 2014). Druga je razlika u tome što neka istraživanja pružaju životinjama specifično iskustvo učenja tijekom faze treninga koja prethodi testu kašnjenja (Heaney i sur., 2017; Melis i sur., 2006a; Plotnik i sur., 2011; Yamamoto i sur., 2019), dok u drugim istraživanjima nema specifičnoga treninga za taj uvjet. Tijekom takvoga treninga životinje prolaze niz pokušaja $u$ kojima se vrijeme kašnjenja partnera postupno povećava tako da prelaze na sljedeće vrijeme kašnjenja tek nakon što su uspješno ,čekale“ partnera u određenome broju pokušaja. U testu se obično koristi mješavina već poznatih i novih vremena kašnjenja (npr. Plotnik i sur., 2011; ali v. Yamamoto i sur., 2019 za primjer gdje test uključuje samo iste duljine kašnjenja kao i trening). U takvim je slučajevima test kašnjenja transfer-test za specifičan trening koji su životinje prošle. Stoga se način kako se ponašanje životinja u testu kašnjenja može interpretirati razlikuje kod istraživanja koja koriste trening i kod onih koja ga ne koriste. U prvome je slučaju test kašnjenja transfer-test za inhibiciju naučenu u treningu - test ispituje mogu li životinje naučenu inhibiciju povlačenja konopa tijekom treninga generalizirati na nove duljine kašnjenja. U drugome je slučaju test kašnjenja transfer-test za situaciju u kojoj su obje životinje imale neposredan pristup aparaturi - test ispituje jesu li životinje tijekom testa $\mathrm{s}$ neposrednim pristupom stekle informaciju o ulozi partnera $u$ rješavanju zadatka.

Nakon ovoga uvodnog opisa istraživanja kooperativnoga rješavanja problema sljedeći će dijelovi rada prikazati u kojoj je mjeri ta literatura zahvaćena istim problemima kao i literatura o socijalnome učenju.

\section{Pristranost prema testiranju socijalnih vrsta?}

Kako bi se prikazalo do koje je mjere literatura o kooperativnome rješavanju problema zahvaćena tendencijom da se testiraju socijalne vrste, kodirane su publikacije o kooperativnome rješavanju problema u posljednjih dvadeset godina $(1990 . \text { - 2019.) })^{1}$. Taj je projekt kodiranja pokazao da za $91 \%$ vrsta (21 od ukupno 23) autori navode da je riječ o socijalnoj vrsti (kod preostalih dviju vrsta za jednu socijalnost nije navedena, a za drugu je nejasna). Za $65 \%$ vrsta (15 od ukupno 23) autori navode kooperativna ponašanja u divljini. Stoga je $95 \%$ kodiranih istraživanja o kooperativnome rješavanju problema (39 od ukupno 41) provedeno na socijalnim vrstama, a $80 \%$ (33 od ukupno 41) na vrstama koje pokazuju kooperativna ponašanja u divljini. Zbog načina odabira istraživanja za kodiranje ne možemo pretpostaviti da te brojke obuhvaćaju sva istraživanja o kooperativnome rješavanju problema. Međutim, navedeni se postoci mogu smatrati reprezentativnima za to područje ako

\footnotetext{
${ }^{1}$ Više informacija o kodiranju, podatci te informacija o pouzdanosti kodiranja dostupno je na https://osf.io/qmfz2/
} 
ne postoji tendencija da istraživanja s nekim ovdje nezastupljenim vrstama koriste drugačiju terminologiju pa zbog toga nisu ušla u grupu kodiranih članaka. Stoga se čini da literatura o kooperativnome rješavanju problema pokazuje istaknutu pristranost prema testiranju socijalnih vrsta, kao i kod socijalnoga učenja. Istovremeno postoji i pristranost prema testiranju vrsta za koje postoje izvješća o kooperativnim ponašanjima u divljini.

Takva pristranost može biti rezultat utjecaja bihevioralne ekologije na modernu komparativnu psihologiju i istraživanja kognicije kod životinja. U istraživanjima kojima je cilj testiranje adaptivne vrijednosti nekoga kooperativnog ponašanja vrsta koja se testira neizbježno će biti ona vrsta koja u divljini pokazuje ponašanje koje se proučava. Međutim, kada su tema istraživanja pitanja poput „Jesu li kognitivne sposobnosti koje omogućuju životinjama da surađuju adaptacija na život u grupama?“, „Koji je selekcijski pritisak mogao dovesti do evolucije kognicije koja omogućuje životinjama da surađuju?“ ili „Koje kognitivne sposobnosti omogućuju životinjama da surađuju?", istaknuti fokus na socijalne vrste i vrste koje pokazuju kooperativna ponašanja u divljini čini se kontraproduktivnim. Prva dva navedena pitanja ne mogu se direktno ispitati ako se ne testiraju vrste raznih razina socijalnosti jer zaključci koji se mogu donijeti na temelju literature - u situacijama u kojima direktan test nije moguć - nikada ne mogu opovrgnuti hipotezu. Što se tiče zadnjega navedenog pitanja, istaknuti fokus na socijalne vrste može i povećati a priori pretpostavku da su kognitivne sposobnosti o kojima je riječ specifično socijalne prirode.

Čini se da je taj argument jaka suprotnost tvrdnjama da možemo razumjeti proksimalne mehanizme kooperacije ako se fokusiramo isključivo na situacije koje su vrlo slične onima u divljini i ako se fokusiramo isključivo na vrste koje pokazuju kooperativna ponašanja u divljini (McAuliffe i Thornton, 2015; v. i Noë, 2006). McAuliffe i Thornton (2015) tvrde da eksperimenti u ,umjetnim“, laboratorijskim uvjetima često dovode do rezultata koji su suprotni onima koji se dobivaju u divljini. Kao primjer autori koriste prosocijalnost kod čimpanzi. U laboratoriju rezultati ukazuju na to da u nekim situacijama čimpanze pokazuju prosocijalna ponašanja, dok su takva ponašanja u divljini rijetka. Međutim, takvi suprotni rezultati možda nužno ne sprečavaju saznanja o evoluciji prosocijalnosti i podaci dobiveni $u$ laboratorijskim uvjetima ne bi se nužno trebali tretirati kao neka vrsta artefakta zato što ne postoje ekvivalentni podaci iz opažanja u divljini. Naprotiv, takve situacije možda nude priliku za identificiranje ograničenja koja djeluju na kognitivne mehanizme koji su vidljivi u laboratorijskim uvjetima i koja mogu objasniti uzorak prosocijalnosti ili kooperacije vidljiv u divljini. Ovdje se može povući analogija s istraživanjima o uporabi alata kod ptica iz porodica vrana, Corvidae. Pretpostavlja se da samo dvije vrste iz porodice Corvidae koriste i same izrađuju alat, naime, vrane Corvus moneduloides na Novoj Kaledoniji (Holzhaider i sur., 2010; Kenward i sur., 2006; Kenward i sur., 2005) i vrane Corvus hawaiiensis na Havajima (Alalã) (Rutz i sur., 2016). Međutim, sve druge vrste iz porodice Corvidae za koje su objavljeni 
testovi u zatočeništvu (gačci [Corvus frugilegus]: Bird i Emery, 2009a, 2009b; kalifornijske šojke [Aphelocoma californica]: Logan i sur., 2016; europske šojke [Garrulus glandarius]: Cheke i sur., 2011) također pokazuju sposobnost korištenja alata, a gačci i sposobnost izrade alata (Bird i Emery, 2009a). Kada vrane Corvus moneduloides i gačci savijaju žicu i izrađuju kuku s kojom naknadno podižu malu kantu iz transparente cijevi od pleksiglasa (Bird i Emery, 2009a; Weir i sur., 2002), malo je vjerojatno da će netko tu situaciju klasificirati kao uporabu alata kod prve vrste, a osporavati istu klasifikaciju kod druge vrste. $U$ tome su slučaju ponašanje ptica i rezultat ponašanja, savijena kuka, vrlo upadljivi. U eksperimentima kooperativnoga rješavanja problema ponašanje možda nije toliko upadljivo, ali to ne znači da ponašanje onih vrsta koje ne surađuju u divljini nije informativno. U slučaju uporabe alata kod pripadnika porodice Corvidae, vrane Corvus moneduloides posjeduju morfološke adaptacije koje olakšavaju izradu i uporabu alata (Martinho i sur., 2014; Matsui i sur., 2016; Troscianko i sur., 2012). Te bi morfološke adaptacije, zajedno s ekologijom vrsta, mogle objasniti distribuciju uporabe alata kod sada živućih vrsta porodice Corvidae (Amodio i sur., 2018). Na sličan način, kada istraživanja o kooperativnome rješavanju zadataka ne bi bila pristrana prema testiranju socijalnih vrsta i onih vrsta koje surađuju u divljini, otvorila bi se mogućnost identificiranja razlika između vrsta na različitim razinama.

\section{Je li kognicija u kooperativnome rješavanju problema specifično socijalna?}

Pretpostavka da se kooperativno rješavanje problema odnosi na kognitivnu sposobnost koja je specifična za neku domenu implicirana je u objavljenoj literaturi ponajprije zbog terminologije koja se koristi u opisivanju ponašanja koja su socijalno orijentirana. Na primjer, te implicitne pretpostavke nalazimo kada autori pišu o socijalnoj kompetenciji (Chalmeau i Gallo, 1995, str. 102), kooperativnoj interakciji (Molesti i Majolo, 2016, str. 133), prirodnoj sposobnosti za timski rad (Drea i Carter, 2009, str. 967) ili formiranju partnerstva (Scheid i Noë, 2010, str. 545). Na eksplicitnije primjere te pretpostavke nailazimo kada autori pišu o kooperaciji kao kognitivnoj adaptaciji (Visalberghi i sur., 2000, str. 300) ili o kooperativnoj kogniciji (Heaney i sur., 2017, str. 1). Heyes (2012b) ističe da je kod istraživanja socijalnoga učenja pretpostavka jedinstveno socijalne kognicije u većini slučajeva implicitna, stoga se čini da je literatura o kooperativnome rješavanju problema u sličnoj poziciji.

Terminologija koja opisuje kooperativno rješavanje problema unutar ovoga preglednog rada odražava terminologiju literature o kooperativnome rješavanju problema. Ta terminologija ukazuje na sljedeću paralelu sa socijalnim učenjem: kognitivni proces koji je uključen u ponašanje ili nije specificiran ili je nedovoljno specificiran. Kada pišu o kogniciji na kojoj se temelji izvedba u testu, autori često govore o kompleksnosti na razini ponašanja. Na primjer, ,prilagodba vlastitih radnji u vremenu i prostoru“ te „razumijevanje kauzalnosti između zahtjeva zadatka i potrebe partnera" ne uključuju navode o tome kako su te sposobnosti povezane sa samim kognitivnim mehanizmima. Na takvu situaciju u literaturi vjerojatno utječe i 
nepostojanje konsenzusa o ulozi učenja u sposobnosti koordiniranja radnji. Neki autori eksplicitno navode da životinje uče kako riješiti zadatak (Chalmeau i Gallo, 1996; Mendres i de Waal, 2000; Ostojić i Clayton, 2014; Vail i sur., 2014; Visalberghi, 1997; Visalberghi i sur., 2000). Međutim, čini se da drugi autori klasificiraju ponašanje životinja u testu kao koordinaciju samo ako se učenje, a posebice asocijativno učenje, može eliminirati kao moguće objašnjenje (de Montaigu i sur., 2019; Eskelinen i sur., 2016; Heaney i sur., 2017; Kuczaj i sur., 2015; Plotnik i sur., 2011). U slučaju socijalnoga učenja Heyes (2012b) i Sterelny (2009) upozorili su na to da pokušaj odvajanja komponenti unutar kognitivnoga procesa može ukazati na problem nedovoljne specifikacije i pomoći pri identificiranju komponenti koje su socijalne prirode i onih koje su opće prirode. Zbog toga su razlikovali sljedeće komponente kognitivnoga procesa: ulazni mehanizam, sadržaj reprezentacije, mehanizam stjecanja i bihevioralni output (Heyes, 2012b). U slučaju socijalnoga učenja predlaže se da je ulazni mehanizam specifično socijalne prirode (Almor, 2003; Heyes, 2012b; Sterelny, 2009), dok je mehanizam stjecanja vjerojatno asocijativno učenje i zbog toga nije specifičan za socijalne situacije (Heyes, 2012b). Stoga će posljednji dio ovoga preglednog rada biti posvećen primjeni iste analize na kooperativno rješavanje problema.

\section{Što je socijalno kod kooperativnoga rješavanja problema?}

Iako postoji varijacija u korištenoj terminologiji, sve definicije koordinacije radnji eksplicitno zahtijevaju da životinje povežu zahtjeve zadatka s potrebom da druga životinja izvede istu ili komplementarnu radnju. Taj se odnos između zahtjeva zadatka i ponašanja druge životinje može smatrati informacijskim sadržajem koji je nužan za uspješno rješavanje kooperativnoga problema. Međutim, te definicije ne govore o tome kako životinje stječu tu informaciju, tj. ne govore o tome kakve prirode mora biti mehanizam stjecanja. Stoga bi izjednačavanje toga što se uči s time kako se uči moglo biti razlog za postojanje različitih i donekle suprotnih stavova o ulozi učenja u koordinaciji, a pogotovo o asocijativnome učenju.

Kako bi kriterij na razini sadržaja reprezentacije bio zadovoljen, životinja mora povezati zahtjeve zadatka $s$ ponašanjem druge životinje, a ne $s$ nekim drugim, nesocijalnim čimbenikom, ili s nekom ne-kauzalno povezanom karakteristikom druge životinje (Albiach-Serrano, 2015; Seed i Jensen, 2011). Životinje moraju prepoznati kada je ta poveznica važna, tj. moraju povezati ponašanje partnera $s$ posebnošću situacije u kojoj je to potrebno (Hake i Vukelich, 1972; Schuster i Perelberg, 2004). Stoga se ponašanja životinje moraju moći klasificirati kao ponašanja usmjerena k cilju (Balleine i Dickinson, 1998; de Wit i Dickinson, 2009), što znači da se mora eliminirati mogućnost da je životinja formirala naviku (v. i Suchak i sur., 2014). Čini se da za stjecanje točne poveznice i njene specifičnosti nije nužno da se implicira novi mehanizam koji je specifičan za kooperativne situacije. Općenamjenski mehanizmi za koje postoje samostalni dokazi iz kognitivne psihologije i kognitivnih znanosti adekvatni su da bi organizam stekao nužni sadržaj 
reprezentacije. $\mathrm{S}$ obzirom na to da testovi kooperativnoga rješavanja problema uključuju brojne pokušaje, a uspješno se rješavanje nagrađuje (hranom), instrumentalno se učenje čini kao vjerojatan mehanizam stjecanja, iako su mogući i drugi mehanizmi (npr. procesi zaključivanja). Moguće je da različiti mehanizmi učenja ili konceptualno znanje u interakciji s instrumentalnim učenjem omogućuju pojedincima ili vrstama iskazivanje kvantitativnih ili kvalitativnih razlika u kooperativnome rješavanju problema. Dok se buduća istraživanja mogu posvetiti takvim pitanjima, u postojećoj literaturi instrumentalno učenje vjerojatno može objasniti izvedbu na testovima. Stoga možemo zaključiti da je mehanizam stjecanja kod kooperativnoga rješavanja problema - pogotovo zbog toga što ne postoji specifikacija nekoga zasebnog mehanizma - vjerojatno općenamjenski mehanizam koji se primjenjuje na socijalnu situaciju.

Sposobnost životinje za identifikaciju da socijalni podražaj kauzalno predviđa uspjeh i da na temelju toga formira točan sadržaj reprezentacije vjerojatno ovisi o njezinoj percepciji, pozornosti i motivaciji te o upadljivosti socijalnoga podražaja u relaciji s drugim (nesocijalnim) podražajima u okolini (Heyes, 2012b; Sterelny, 2009). Kod kooperativnoga rješavanja problema istraživanja često obuhvaćaju takve čimbenike, npr. bliskost i toleranciju između partnera (Hare i sur., 2007; Melis i sur., 2006b; Scheid i Noë, 2010; Seed i sur., 2008). Nakon stjecanja informacije kako riješiti zadatak $i$ formiranja sadržaja reprezentacije uspješna izvedba u testu kooperativnoga rješavanja problema ovisit će i o tome u kojoj mjeri životinja može koristiti tu informaciju za prilagodbu vlastite radnje ponašanju partnera u vremenu i prostoru. Stoga će koordinacija kao ponašajni ishod zavisiti o sposobnosti životinje da planira svoje radnje i o njezinim inhibitornim sposobnostima (Baker i Rachlin, 2002). Izvedba koordinirane radnje s drugom životinjom potencijalno zahtijeva veću razinu izvršnih funkcija nego prilagodba radnje kretanju predmeta jer su kretnje drugih životinja kompleksnije i nepredvidljivije od kretnji predmeta. Razlike između pojedinaca ili vrsta mogle bi postojati i u toj komponenti. S druge strane, sposobnost izvedbe ponašajnoga ishoda može utjecati na sposobnost učenja tijekom testa. To bi ukazivalo na to da je kognitivni proces u kooperativnome rješavanju problema povezan is fizičkim procesima (Barrett, 2012).

Načelno, vrste se mogu razlikovati bilo u kojoj komponenti kognitivnoga procesa. Odvajanje različitih komponenti omogućuje diferenciranje situacije u kojoj se vrste razlikuju u općemu kognitivnome mehanizmu od situacije u kojoj se vrste razlikuju u procesima pozornosti, percepcije ili motivacije. U drugome slučaju ti nekognitivni procesi mogu utjecati na to može li životinja ili koliko brzo može identificirati da je socijalni podražaj, tj. partner relevantan, i/ili na to koliko precizno životinja može svoje radnje prilagoditi ponašanju partnera. Postoje rezultati koji ukazuju na to da se neke razlike između vrsta temelje na takvim ne-kognitivnim čimbenicima. Marshall-Pescini i suradnici $(2017,2018)$ interpretiraju konzistentne razlike između pasa i vukova u svojim istraživanjima u testu „slobodnoga konopa“ kao rezultat veće međusobne tolerancije kod vukova zbog lova u grupama. Hare i 
suradnici (2007) predlažu da temperament igra barem izvjesnu ulogu u objašnjenju varijacije u kooperativnome rješavanju problema između vrsta nakon što su uočili da bonobo majmuni (Pan paniscus) bolje rješavaju test nego čimpanze, vjerojatno zbog visoke razine međusobne tolerancije. Moguće je da je, kao što je predloženo za socijalno učenje, došlo do evolucije predispozicija percepcije, pozornosti i/ili motivacije koje ograničavaju opće mehanizme i tako olakšavaju kooperativno rješavanje problema.

\section{Implikacije za budućnost istraživanja kooperativnoga rješavanja problema}

Analiza provedena u ovome radu može biti korisna pri definiranju prijedloga za razvoj toga istraživačkog područja. Kao prvi korak čini se da je važno postići bolju integraciju s kognitivnom psihologijom, tj. kognitivnim znanostima kako bi se, prvo, definirale komponente kognitivnoga procesa koje su od interesa, i drugo, kako bi se istražilo koji kognitivni mehanizmi najbolje objašnjavaju uspjeh u zadacima kooperativnoga rješavanja problema. Takav bi pristup zahtijevao veću pažnju pri korištenju terminologije i uvažavanje kognitivnih mehanizama za koje postoje samostalni dokazi iz drugih istraživanja i za koje potencijalno postoje formalne teorije. U slučaju kooperativnoga rješavanja problema to bi se primarno odnosilo na teoriju učenja i na razne mehanizme učenja. Važno je napomenuti da unutar istraživanja teorije učenja postoje istraživanja o kooperativnome rješavanju problema koja koriste operantni pristup (de Carvalho i sur., 2018; Łopuch i Popik, 2011; Rosenbaum i Epley, 1971; Schuster, 2002; Tan i Hackenberg, 2016; Velasco i sur., 2017). Dvije su razlike između ranije navedenih zadataka kooperativnoga rješavanja problema i tih operantnih testova. Prva je razlika u tome što operantni testovi imaju manju ekološku valjanost jer je kauzalni mehanizam nevidljiv. U tipičnome testu dvije životinje (većinom smeđi štakori, Rattus norvegicus, ili golubi pećinari, Columba livia) rješavaju zadatak tako da obje u isto vrijeme pritisnu polugu ili tipku kako bi dobile otopinu saharoze ili hranu. Druga je razlika u tome što operantni testovi eksplicitno i direktno ispituju učenje životinja u kooperativnome zadatku i čimbenike koji utječu na učenje. Trenutno ne postoji dobra integracija između tih različitih pristupa, pa tako članci s jednim pristupom gotovo nikada ne spominju literaturu koja se temelji na drugome pristupu (za iznimke v. Massen i sur., 2019 i Tan i Hackenberg, 2016). Jedan je mogući uzrok tomu što različita literatura možda koristi različitu terminologiju pa zbog toga ne dolazi do preklapanja. To je ujedno vjerojatno i razlog zbog kojega je samo jedan članak s operantnim pristupom ušao u grupu kodiranih članaka za ovaj pregledni rad (Velasco i sur., 2017). Veća integracija između pristupa i literature bila bi korisna kako bi se jasnije ispitao kognitivni mehanizam koji je uključen u kooperativno rješavanje zadataka, što je i tema većine operantnih testova u tome području.

Drugi pristup koji bi mogao biti koristan u identificiranju i testiranju različitih komponenti kognitivnoga procesa integracija je empirijskih istraživanja $s$ komputacijskim modeliranjem. Primjer takve integracije u području kooperativnoga 
rješavanja problema istraživanje je Fruteau i suradnika (2013). Autori modeliranjem ukazuju da individualno učenje najbolje objašnjava ponašanje grupe verveta (Chlorocebus pygerythrus) u rješavanju grupnoga kooperativnog zadatka. Drugi istraživači u tome području još nisu implementirali taj pristup, iako bi komputacijsko modeliranje moglo biti korisno i kod sada već prikupljenih podataka iz raznih istraživanja. To bi moglo predstavljati koristan sljedeći korak u identifikaciji različitih komponenti kognitivnoga procesa i prirode kognitivnoga mehanizma $\mathrm{u}$ kooperativnome rješavanju problema.

$\mathrm{Na}$ funkcionalnoj razini analize svaka od komponenti koje su uključene $\mathrm{u}$ kooperativno ponašanje mogla bi se razlikovati između vrsta i mogla bi biti adaptacija na neki određeni ekološki problem. Stoga bi istraživanja o evoluciji kooperativnih ponašanja trebala razmotriti i uključiti razne elemente kognitivnoga procesa u svoje teoretske modele i svoja empirijska testiranja, i to bez a priori pretpostavke da se razlike u ponašanju nužno moraju temeljiti na razlikama $u$ kognitivnome elementu. Dosad su komparativna istraživanja u literaturi o kooperativnome rješavanju problema uvažila međusobnu toleranciju kao moguću razliku između vrsta (Hare i sur., 2007; Marshall-Pescini i sur., 2017, 2018). Međutim, istraživanja bi mogla ispitati razlike između vrsta i u drugim aspektima, npr. u motivaciji za kooperaciju, procesima percepcije, sustavu pozornosti. U nedavno objavljenome radu Massen i suradnici (2019) predlažu da se tim aspektima dodaju i afektivni procesi. Autori naglašavaju da nedavni napredak u tehnologiji omogućuje mjerenje simpatičkih procesa i hormona čak i u grupnim situacijama, pa komparativna istraživanja mogu ispitati postoje li razlike u emocionalnim i afektivnim reakcijama kod različitih vrsta koje utječu na kooperaciju ili koje se pojavljuju kao rezultat kooperativnoga ponašanja (Massen i sur., 2019). Upravo bi motivacijski i afektivni procesi mogli predstavljati mehanizme koji su uključeni $u$ kognitivni proces kod kooperativnoga rješavanja problema, a koji su specifično socijalne prirode. Moguće je da se interakcija s drugim pojedincem upravo u tim mehanizmima razlikuje od interakcije s nekim predmetom. Stoga su možda ti mehanizmi ključni čimbenici koji mogu objasniti razlike u kooperativnome ponašanju između vrsta. Naposljetku, važno je još jednom napomenuti da bi istraživanja o evoluciji kooperativnih ponašanja morala obuhvaćati vrste s različitim stupnjevima socijalnosti te vrste koje u divljini ne surađuju.

\section{Zaključak}

Kako bi se ispitala evolucija socijalnih kognitivnih sposobnosti, istraživanja socijalne kognicije kod životinja trebala bi biti jače povezana s teorijskim okvirima unutar kognitivne psihologije i kognitivnih znanosti. Ovaj pregledni rad pokazao je da u istraživanjima kooperativnoga rješavanja problema zbog nedovoljne integracije postoje slični problemi poput onih na koje je prijašnja analiza ukazala kod socijalnoga učenja. Prvi je problem pristranost prema testiranju socijalnih vrsta, a 
drugi je a priori pretpostavka da je kognicija unutar kooperativnoga rješavanja zadataka specifično socijalne prirode. Ovaj rad ukazuje na to da je ta pretpostavka neutemeljena: kognitivni mehanizam u kooperativnome rješavanju zadataka vjerojatno je općenamjenski mehanizam koji se primjenjuje na situaciju u kojoj je jedan od glavnih poticaja socijalan. Moguće je da su neke vrste evoluirale procese percepcije, pozornosti, motivacije ili afektivne procese koji im olakšavaju primjenu općega mehanizma u socijalnim situacijama, možda u obliku predispozicija. Ispitivanje koje su komponente kognitivnoga procesa u kooperativnome rješavanju zadataka evoluirale zbog selekcijskoga pritiska života u grupama bit će moguće samo ako istraživanja uključe vrste $s$ raznim razinama socijalnosti te ako objavljena literatura smanji trenutnu pristranost prema socijalnim vrstama.

\section{Literatura}

Albiach-Serrano, A. (2015). Cooperation in primates: A critical, methodological review. Interaction Studies, 16(3), 361-382. https://doi.org/10.1075/is.16.3.02alb

Almor, A. (2003). Specialized behavior without specialized modules: The massive adaptability hypothesis. U: D. Over (Ur.), Evolution \& the Psychology of Thinking: The Debate (str. 101-120). Psychology Press.

Amodio, P., Jelbert, S. A. i Clayton, N. S. (2018). The interplay between psychological predispositions and skill learning in the evolution of tool use. Current Opinion in Behavioral Sciences, 20, 130-137. https://doi.org/10.1016/j.cobeha.2018.01.002

Asakawa-Haas, K., Schiestl, M., Bugnyar, T. i Massen, J. J. M. (2016). Partner choice in raven (Corvus corax) cooperation. PLOS ONE, 11(6). https://doi.org/10.1371/journal. pone. 0156962

Ashton, B. J., Thornton, A. i Ridley, A. R. (2018). An intraspecific appraisal of the social intelligence hypothesis. Philosophical Transactions of the Royal Society B: Biological Sciences, 373(1756), 20170288. https://doi.org/10.1098/rstb.2017.0288

Baker, F. i Rachlin, H. (2002). Self-control by pigeons in the prisoner's dilemma. Psychonomic Bulletin and Review, 9(3), 482-488. https://doi.org/10.3758/BF03196303

Balleine, B. W. i Dickinson, A. (1998). Goal-directed instrumental action: Contingency and incentive learning and their cortical substrates. Neuropharmacology, 37(4-5), 407-419. https://doi.org/10.1016/S0028-3908(98)00033-1

Barrett, L. (2012). Why behaviorism isn't satanism. U: T. K. Shackelford i J. Vonk (Ur.), The Oxford Handbook of Comparative Evolutionary Psychology (str. 17-38). Oxford University Press. https://doi.org/10.1093/oxfordhb/9780199738182.013.0002

Behrens, T. E. J., Hunt, L. T., Woolrich, M. W. i Rushworth, M. F. S. (2008). Associative learning of social value. Nature, 456(7219), 245-249. https://doi.org/10.1038/ nature 07538 
Bird, C. D. i Emery, N. J. (2009a). Insightful problem solving and creative tool modification by captive nontool-using rooks. Proceedings of the National Academy of Sciences of the United States of America, 106(25), 10370-10375. https://doi.org/10.1073/pnas. 0901008106

Bird, C. D. i Emery, N. J. (2009b). Rooks use stones to raise the water level to reach a floating worm. Current Biology, 19(16), 1410-1414. https://doi.org/10.1016/j.cub.2009.07.033

Boesch, C. i Boesch, H. (1989). Hunting behavior of wild chimpanzees in the Taï National Park. American Journal of Physical Anthropology, 78(4), 547-573. https://doi.org/10. 1002/ajpa.1330780410

Boogert, N. J., Giraldeau, L. A. i Lefebvre, L. (2008). Song complexity correlates with learning ability in zebra finch males. Animal Behaviour, 76(5), 1735-1741. https://doi.org/10.1016/j.anbehav.2008.08.009

Bouchard, J., Goodyer, W. i Lefebvre, L. (2007). Animal Cognition, 10, 259-266. https://doi.org/10.1007/s10071-006-0064-1

Boucherie, P. H., Loretto, M. C., Massen, J. J. M. i Bugnyar, T. (2019). What constitutes "social complexity" and "social intelligence" in birds? Lessons from ravens. Behavioral Ecology and Sociobiology, 73(1), 12. https://doi.org/10.1007/s00265-018-2607-2

Brosnan, S. F., Talbot, C., Ahlgren, M., Lambeth, S. P. i Schapiro, S. J. (2010). Mechanisms underlying responses to inequitable outcomes in chimpanzees, Pan troglodytes. Animal Behaviour, 79(6), 1229-1237. https://doi.org/10.1016/j.anbehav.2010.02.019

Byrne, R. W. i Bates, L. A. (2007). Sociality, evolution and cognition. Current Biology, 17(16), R714-R723. https://doi.org/10.1016/j.cub.2007.05.069

Byrne, R. W. i Whiten, A. (1988). Machiavellian intelligence: Social expertise and the evolution of intellect in monkeys, apes, and humans. Oxford University Press.

Carlier, P. i Lefebvre, L. (1997). Ecological differences in social learning between adjacent, mixing, populations of zenaida doves. Ethology, 103(9), 772-784. https://doi.org/10. 1111/j.1439-0310.1997.tb00185.x

Chalmeau, R. i Gallo, A. (1995). Cooperation in primates: Critical analysis of behavioural criteria. Behavioural Processes, 35(1-3), 101-111. https://doi.org/10.1016/0376-6357 (95)00049-6

Chalmeau, R. i Gallo, A. (1996). What chimpanzees (Pan troglodytes) learn in a cooperative task. Primates, 37(1), 39-47. https://doi.org/10.1007/BF02382918

Cheke, L. G., Bird, C. D. i Clayton, N. S. (2011). Tool-use and instrumental learning in the Eurasian jay (Garrulus glandarius). Animal Cognition, 14(3), 441-455. https://doi.org/10.1007/s10071-011-0379-4

Cheney, D. L. i Seyfarth, R. (1990). How Monkeys see the world. Inside the mind of another species. University of Chicago Press.

Crawford, M. P. (1937). The cooperative solving of problems by young Chimpanzees. Comparative Psychology Monographs, 14, 1-88. 
de Carvalho, L. C., Dos Santos, L., Regaço, A., Barbosa, T. B., Da Silva, R. F., De Souza, D. D. G. i Sandaker, I. (2018). Cooperative responding in rats maintained by fixed- and variable-ratio schedules. Journal of the Experimental Analaysis and Behavior, 110(1), 105-126. https://doi.org/10.1002/jead.457

de Montaigu, C. T., Durdevic, K., Brucks, D., Krasheninnikova, A. i von Bayern, A. (2019). Blue-throated macaws (Ara glaucogularis) succeed in a cooperative task without coordinating their actions. Ethology, 126, 267-277. https://doi.org/10.1111/eth.12973

de Wit, S. i Dickinson, A. (2009). Associative theories of goal-directed behaviour: A case for animal-human translational models. Psychological Research, 73(4), 463-476. https://doi.org/10.1007/s00426-009-0230-6

Dolman, C. S., Templeton, J. i Lefebvre, L. (1996). Mode of foraging competition is related to tutor preference in Zenaida aurita. Journal of Comparative Psychology, 110(1), 4554. https://doi.org/10.1037/0735-7036.110.1.45

Doody, J. S., Burghardt, G. M. i Dinets, V. (2013). Breaking the social-non-social dichotomy: A role for reptiles in vertebrate social behavior research? Ethology, 119(2), 95-103. https://doi.org/10.1111/eth.12047

Drea, C. M. i Carter, A. N. (2009). Cooperative problem solving in a social carnivore. Animal Behaviour, 78(4), 967-977. https://doi.org/10.1016/j.anbehav.2009.06.030

Dugatkin, L. A. (1997). Cooperation among animals: An evolutionary perspective. Oxford University Press. https://doi.org/10.5860/choice.35-0904

Dugatkin, L. A. (2002). Cooperation in animals: An evolutionary overview. Biology and Philosophy, 17(4), 459-476. https://doi.org/10.1023/A:1020573415343

Dunbar, R. I. M. (1992). Neocortex size as a constraint size in primates on group ecologically. Journal of Human Evolution, 20, 469-493.

Dunbar, R. I. M. (1998). The social brain hypothesis. Evolutionary Anthropology, 6(5), 178190. https://doi.org/10.1002/(SICI)1520-6505(1998)6:5<178::AID-EVAN5>3.0.CO;2-8

Dyer, A. G., Neumeyer, C. i Chittka, L. (2005). Honeybee (Apis mellifera) vision can discriminate between and recognise images of human faces. Journal of Experimental Biology, 208(24), 4709-4714. https://doi.org/10.1242/jeb.01929

Emery, N. J. i Clayton, N. S. (2004). The mentality of crows: Convergent evolution of intelligence in corvids and apes. Science, 306(5703), 1903-1907. https://doi.org/10. 1126/science. 1098410

Emery, N. J., Seed, A. M., Von Bayern, A. M. P. i Clayton, N. S. (2007). Cognitive adaptations of social bonding in birds. Philosophical Transactions of the Royal Society B: Biological Sciences, 362(1480), 489-505. https://doi.org/10.1098/rstb.2006.1991

Eskelinen, H. C., Winship, K. A., Jones, B. L., Ames, A. E. M. i Kuczaj, S. A. (2016). Acoustic behavior associated with cooperative task success in bottlenose dolphins (Tursiops truncatus). Animal Cognition, 19(4), 789-797. https://doi.org/10.1007/ s10071-016-0978-1

Fehr, E. i Fischbacher, U. (2004). Social norms and human cooperation. Trends in Cognitive Sciences, 8(4), 185-190. https://doi.org/10.1016/j.tics.2004.02.007 
Fiorito, G. i Scotto, P. (1992). Observational learning in Octopus vulgaris. Science, 256(5056), 545-547. https://doi.org/10.126/science.256.5056.545

Fraser, O. N. i Bugnyar, T. (2010). The quality of social relationships in ravens. Animal Behaviour, 79(4), 927-933. htps://doi.org/10.1016/j.anbehav.2010.01.008

Fruteau, C., van Damme, E. i Noë, R. (2013). Vervet monkeys solve a multiplayer "forbidden circle game" by queuing to learn restraint. Current Biology, 23(8), 665-670. https://doi.org/10.1016/j.cub.2013.02.039

Galef, B. G. (1981). Development of olfactory control of feeding-site selection in rat pups. Journal of Comparative and Physiological Psychology, 95(4), 615-622. https://doi.org/10.1037/h0077792

Gould, S. J. i Lewontin, R. C. (1979). The spandrels of San Marco and the Panglossian paradigm: A critique of the adaptationist programme. Proceedings of the Royal Society of London - Biological Sciences, 205(1161), 581-598. https://doi.org/10.1098/rspb. 1979.0086

Hake, D. F. i Vukelich, R. (1972). A classification and review of cooperation procedures. Journal of the Experimental Analysis of Behavior, 18, 333-345. https://doi.org/10.1901/ jeab.1972.18-333

Hare, B., Melis, A. P., Woods, V., Hastings, S. i Wrangham, R. (2007). Tolerance allows bonobos to outperform chimpanzees on a cooperative task. Current Biology, 17(7), 619623. https://doi.org/10.1016/j.cub.2007.02.040

Heaney, M., Gray, R. D. i Taylor, A. H. (2017). Keas perform similarly to chimpanzees and elephants when solving collaborative tasks. PLOS ONE, 12(2). https://doi.org/10.1371/ journal.pone.0169799

Heyes, C. (2012a). Simple minds: A qualified defence of associative learning. Philosophical Transactions of the Royal Society B: Biological Sciences, 367(1603), 2695-2703. https://doi.org/10.1098/rstb.2012.0217

Heyes, C. (2012b). What's social about social learning? Journal of Comparative Psychology, 126(2), 193-202. https://doi.org/10.1037/a0025180

Heyes, C. M. (1994). Social learning in animals: Categories and mechanisms. Biological Reviews of the Cambridge Philosophical Society, 69(2), 207-231. https://doi.org/10. 1111/j.1469-185x.1994.tb01506.x

Hirata, S. i Fuwa, K. (2007). Chimpanzees (Pan troglodytes) learn to act with other individuals in a cooperative task. Primates, 48(1), 13-21. https://doi.org/10.1007/s10329-006-0022-1

Holzhaider, J. C., Hunt, G. R. i Gray, R. D. (2010). The development of pandanus tool manufacture in wild New Caledonian crows. Behaviour, 147(5-6), 553-586. https://doi.org/10.1163/000579510X12629536366284

Hoppitt, W. i Laland, K. N. (2008). Social processes influencing learning in animals: A review of the evidence. Advances in the Study of Behavior 38, 105-165. https://doi.org/10.1016/S0065-3454(08)00003-X

Humphrey, N. K. (1976). The social function of intellect. U: P. P. Bateson i R. A. Hinde (Ur.), Growing points in ethology (str. 303-317). Cambridge University Press. 
Jaakkola, K., Guarino, E., Donegan, K. i King, S. L. (2018). Bottlenose dolphins can understand their partner's role in a cooperative task. Proceedings of the Royal Society B: Biological Sciences, 285(1887). https://doi.org/10.1098/rspb.2018.0948

Jelbert, S. A., Singh, P. J., Gray, R. D. i Taylor, A. H. (2015). New Caledonian crows rapidly solve a collaborative problem without cooperative cognition. PLOS ONE, 10(8). https://doi.org/10.1371/journal.pone.0133253

Jolly, A. (1966). Lemur social behavior and primate intelligence. Science, 153(3735), 501506. https://doi.org/10.1126/science.153.3735.501

Kaigaishi, Y., Nakamichi, M. i Yamada, K. (2019). High but not low tolerance populations of Japanese macaques solve a novel cooperative task. Primates, 60(5), 421-430. https://doi.org/10.1007/s10329-019-00742-z

Kar, F., Whiting, M. J. i Noble, D. W. A. (2017). Dominance and social information use in a lizard. Animal Cognition, 20(5), 805-812. https://doi.org/10.1007/s10071-017-1101-y

Kenward, B., Rutz, C., Weir, A. A. S. i Kacelnik, A. (2006). Development of tool use in New Caledonian crows: Inherited action patterns and social influences. Animal Behaviour, 72(6), 1329-1343. https://doi.org/10.1016/j.anbehav.2006.04.007

Kenward, B., Weir, A. A. S., Rutz, C. i Kacelnik, A. (2005). Tool manufacture by naive juvenile crows. Nature, 433, 121. https://doi.org/10.1038/nature03294

Kis, A., Huber, L. i Wilkinson, A. (2015). Social learning by imitation in a reptile (Pogona vitticeps). Animal Cognition, 18(1), 325-331. https://doi.org/10.1007/s10071-014-0803-7

Klein, J. T., Deaner, R. O. i Platt, M. L. (2008). Neural correlates of social target value in macaque parietal cortex. Current Biology, 18(6), 419-424. https://doi.org/10.1016/j. cub.2008.02.047

Klopfer, P. (1959). Social interactions in discrimination learning. Animal Behaviour, 7(1-2), 112-113. https://doi.org/10.1016/0003-3472(59)90045-4

Kuczaj, S. A., Winship, K. A. i Eskelinen, H. C. (2015). Can bottlenose dolphins (Tursiops truncatus) cooperate when solving a novel task? Animal Cognition, 18(2), 543-550. https://doi.org/10.1007/s10071-014-0822-4

Lefebvre, L. i Giraldeau, L.-A. (1996). Is social learning an adaptive specialization? U: C. Heyes i B. Galef (Ur.), Social learning in animals: The roots of culture (str. 107-128). Academic Press. https://doi.org/10.1016/B978-012273965-1/50007-8

Lefebvre, L., Palameta, B. i Hatch, K. K. (1996). Is group-living associated with social learning? A comparative test of a gregarious and a territorial columbid. Behaviour, 133(3-4), 241-261. https://doi.org/10.1163/156853996x00134

Logan, C. J., Harvey, B. D., Schlinger, B. A. i Rensel, M. (2016). Western scrub-jays do not appear to attend to functionality in Aesop's Fable experiments. PeerJ, 2016(2). https://doi.org/10.7717/peerj.1707

Łopuch, S. i Popik, P. (2011). Cooperative behavior of laboratory rats (Rattus norvegicus) in an instrumental task. Journal of Comparative Psychology, 125(2), 250-253. https://doi.org/10.1037/a0021532 
Marshall-Pescini, S., Basin, C. i Range, F. (2018). A task-experienced partner does not help dogs be as successful as wolves in a cooperative string-pulling task. Scientific Reports, 8(1). https://doi.org/10.1038/s41598-018-33771-7

Marshall-Pescini, S., Schwarz, J. F. L., Kostelnik, I., Virányi, Z. i Range, F. (2017). Importance of a species' socioecology: Wolves outperform dogs in a conspecific cooperation task. Proceedings of the National Academy of Sciences of the United States of America, 114(44), 11793-11798. https://doi.org/10.1073/pnas.1709027114

Martinho, A., Burns, Z. T., Von Bayern, A. M. P. i Kacelnik, A. (2014). Monocular tool control, eye dominance, and laterality in New Caledonian crows. Current Biology, 24(24), 2930-2934. https://doi.org/10.1016/j.cub.2014.10.035

Marzluff, J. M., Walls, J., Cornell, H. N., Withey, J. C. i Craig, D. P. (2010). Lasting recognition of threatening people by wild American crows. Animal Behaviour, 79(3), 699-707. https://doi.org/10.1016/j.anbehav.2009.12.022

Massen, J. J. M., Behrens, F., Martin, J. S., Stocker, M. i Brosnan, S. F. (2019). A comparative approach to affect and cooperation. Neuroscience and Biobehavioral Reviews, 107, 370-387. https://doi.org/10.1016/j.neubiorev.2019.09.027

Massen, J. J. M., Ritter, C. i Bugnyar, T. (2015). Tolerance and reward equity predict cooperation in ravens (Corvus corax). Scientific Reports, 5. https://doi.org/10.1038/ srep15021

Matsui, H., Hunt, G. R., Oberhofer, K., Ogihara, N., McGowan, K. J., Mithraratne, K., Yamasaki, T., Gray, R. D. i Izawa, E. I. (2016). Adaptive bill morphology for enhanced tool manipulation in New Caledonian crows. Scientific Reports, 6. https://doi.org/10.1038/srep22776

McAuliffe, K. i Thornton, A. (2015). The psychology of cooperation in animals: An ecological approach. Journal of Zoology, 295(1), 23-35. https://doi.org/10.1111/jzo.12204

Melis, A. P., Hare, B. i Tomasello, M. (2006a). Chimpanzees recruit the best collaborators. Science, 311(5765), 1297-1300. https://doi.org/10.1126/science.1123007

Melis, A. P., Hare, B. i Tomasello, M. (2006b). Engineering cooperation in chimpanzees: Tolerance constraints on cooperation. Animal Behaviour, 72(2), 275-286. https://doi.org/10.1016/j.anbehav.2005.09.018

Melis, A. P. i Semmann, D. (2010). How is human cooperation different? Philosophical Transactions of the Royal Society B: Biological Sciences, 365(1553), 2663-2674. https://doi.org/10.1098/rstb.2010.0157

Mendres, K. A. i de Waal, F. B. M. (2000). Capuchins do cooperate: The advantage of an intuitive task. Animal Behaviour, 60(4), 523-529. https://doi.org/10.1006/anbe.2000.1512

Miller, N. i Dollard, J. (1941). Social learning and imitation. Yale University Press.

Molesti, S. i Majolo, B. (2016). Cooperation in wild Barbary macaques: Factors affecting free partner choice. Animal Cognition, 19(1), 133-146. https://doi.org/10.1007/s10071-0150919-4

Noble, D. W. A., Byrne, R. W. i Whiting, M. J. (2014). Age-dependent social learning in a lizard. Biology Letters, 10(7). https://doi.org/10.1098/rsbl.2014.0430 
Noë, R. (2006). Cooperation experiments: Coordination through communication versus acting apart together. Animal Behaviour, 71(1), 1-18 https://doi.org/10.1016/j.anbehav. 2005.03.037

Ostojić, L. i Clayton, N. S. (2014). Behavioural coordination of dogs in a cooperative problem-solving task with a conspecific and a human partner. Animal Cognition, 17(2), 445-459. https://doi.org/10.1007/s10071-013-0676-1

Péron, F., Rat-Fischer, L., Lalot, M., Nagle, L. i Bovet, D. (2011). Cooperative problem solving in African grey parrots (Psittacus erithacus). Animal Cognition, 14(4), 545-553. https://doi.org/10.1007/s10071-011-0389-2

Plotnik, J. M., Lair, R., Suphachoksahakun, W. i de Waal, F. B. M. (2011). Elephants know when they need a helping trunk in a cooperative task. Proceedings of the National Academy of Sciences of the United States of America, 108(12), 5116-5121. https://doi.org/10.1073/pnas.1101765108

Reader, S. M., Hager, Y. i Laland, K. N. (2011). The evolution of primate general and cultural intelligence. Philosophical Transactions of the Royal Society B: Biological Sciences, 366(1567), 1017-1027. https://doi.org/10.1098/rstb.2010.0342

Reader, S. M. i Laland, K. N. (2002). Social intelligence, innovation, and enhanced brain size in primates. Proceedings of the National Academy of Sciences of the United States of America, 99(7), 4436-4441. https://doi.org/10.1073/pnas.062041299

Rosenbaum, M. E. i Epley, S. W. (1971). Cooperation in rats without prior individual training. Psychonomic Science, 24(1), 34-36. https://doi.org/10.3758/BF03331764

Rutz, C., Klump, B. C., Komarczyk, L., Leighton, R., Kramer, J., Wischnewski, S., Sugasawa, S., Morrissey, M. B., James, R., St Clair, J. J. H., Switzer, R. A. i Masuda, B. M. (2016). Discovery of species-wide tool use in the Hawaiian crow. Nature, 537(7620), 403-407. https://doi.org/10.1038/nature19103

Scheid, C. i Noë, R. (2010). The performance of rooks in a cooperative task depends on their temperament. Animal Cognition, 13, 545-553. https://doi.org/10.1007/s10071-009-0305-1

Schmelz, M., Duguid, S., Bohn, M. i Völter, C. J. (2017). Cooperative problem solving in giant otters (Pteronura brasiliensis) and Asian small-clawed otters (Aonyx cinerea). Animal Cognition, 20(6), 1107-1114. https://doi.org/10.1007/s10071-017-1126-2

Schuster, R. (2002). Cooperative coordination as a social behavior. Human Nature, 13, 4783. https://doi.org/10.1007/s12110-002-1014-5

Schuster, R. i Perelberg, A. (2004). Why cooperate? An economic perspective is not enough. Behavioural Processes, 66(3), 261-277. https://doi.org/10.1016/j.beproc.2004.03.008

Seed, A. M., Clayton, N. S. i Emery, N. J. (2008). Cooperative problem solving in rooks (Corvus frugilegus). Proceedings of the Royal Society B: Biological Sciences, 275(1641), 1421-1429. https://doi.org/10.1098/rspb.2008.0111

Seed, A. M. i Jensen, K. (2011). Large-scale cooperation. Nature, 472(7344), 424-425. https://doi.org/10.1038/472424a

Shettleworth, S. J. (1998). Cognition, evolution, and behavior. Oxford University Press. 
Shultz, S. i Dunbar, R. I. M. (2007). The evolution of the social brain: Anthropoid primates contrast with other vertebrates. Proceedings of the Royal Society B: Biological Sciences, 274(1624), 2429-2436. https://doi.org/10.1098/rspb.2007.0693

Sterelny, K. (2009). Peacekeeping in the culture wars. U: K. N. Laland i B. Galef (Ur.), The question of animal culture (str. 288-304). Harvard University Press.

Stevens, J. R., Cushman, F. A. i Hauser, M. D. (2005). Evolving the psychological mechanisms for cooperation. Annual Review of Ecology, Evolution, and Systematics, 36, 499-518. https://doi.org/10.1146/annurev.ecolsys.36.113004.083814

Stevens, J. R. i Hauser, M. D. (2004). Why be nice? Psychological constraints on the evolution of cooperation. Trends in Cognitive Sciences, 8(2), 60-65. https://doi.org/10.1016/j.tics. 2003.12.003

Suchak, M., Eppley, T. M., Campbell, M. W. i de Waal, F. B. M. (2014). Ape duos and trios: Spontaneous cooperation with free partner choice in chimpanzees. PeerJ, 2014(1). https://doi.org/10.7717/peerj.417

Tan, L. i Hackenberg, T. D. (2016). Functional analysis of mutual behavior in laboratory rats (Rattus norvegicus). Journal of Comparative Psychology, 130(1), 13-23. https://doi.org/10.1037/com0000015

Thornton, A. i Raihani, N. J. (2008). The evolution of teaching. Animal Behaviour, 75(6), 1823-1836. https://doi.org/10.1016/j.anbehav.2007.12.014

Tomasello, M. (1995). Joint attention as social cognition. U: C. Moore i P. J. Dunham (Ur.), Joint Attention: Its Origins and Role in Development (str. 103-130). Psychology Press.

Troscianko, J., Von Bayern, A. M. P., Chappell, J., Rutz, C. i Martin, G. R. (2012). Extreme binocular vision and a straight bill facilitate tool use in New Caledonian crows. Nature Communications, 3. https://doi.org/10.1038/ncomms2111

Vail, A. L., Manica, A. i Bshary, R. (2014). Fish choose appropriately when and with whom to collaborate. Current Biology, 24(17), R791-R793. https://doi.org/10.1016/j.cub. 2014.07.033

Velasco, A. M., Benvenuti, M. F. L., Sampaio, A. A. S. i Tomanari, G. Y. (2017). Cooperation and metacontingency in pigeons. The Psychological Record, 67, 537-545. https://doi.org/10.1007/s40732-017-0256-X

Visalberghi, E. (1997). Success and understanding in cognitive tasks: A comparison between Cebus apella and Pan troglodytes. International Journal of Primatology, 18(5), 811830. https://doi.org/10.1023/A:1026399930727

Visalberghi, E., Quarantotti, B. P. i Tranchida, F. (2000). Solving a cooperation task without taking into account the partner's behavior: The case of capuchin monkeys (Cebus apella). Journal of Comparative Psychology, 114(3), 297-301. https://doi.org/10.1037/ 0735-7036.114.3.297

Weir, A. A. S., Chappell, J. i Kacelnik, A. (2002). Shaping of hooks in New Caledonian crows. Science, 297(5583), 981. https://doi.org/10.1126/science.1073433 
Wilkinson, A., Kuenstner, K., Mueller, J. i Huber, L. (2010). Social learning in a non-social reptile (Geochelone carbonaria). Biology Letters, 6(5), 614-616. https://doi.org/10. 1098/rsbl.2010.0092

Whiten, A. i Byrne, R. (1997). Machiavellian intelligence II: Evaluations and extensions. Cambridge University Press.

Yamamoto, C., Kashiwagi, N., Otsuka, M., Sakai, M. i Tomonaga, M. (2019). Cooperation in bottlenose dolphins: Bidirectional coordination in a rope-pulling task. PeerJ, 2019(10). https://doi.org/10.7717/peerj.7826

\title{
Methodological and Conceptual Issues in Studying the Evolution of Social Behaviour: The Case of Cooperative Problem-Solving
}

\begin{abstract}
A major research area in non-human social cognition is the investigation of cooperative problemsolving, i.e. the cognition involved in situations when animals cooperate with each other. Social cognition is thought to have evolved due to the demands of social living and is often thought to present an adaptive specialisation for living in groups. A previous analysis of social learning, another area of social cognition, has highlighted how this has consequently led to two overarching biases in the literature: firstly, a bias towards testing only social species, and secondly, an a priori assumption that social learning is qualitatively different from learning involved in non-social situations. The problem of these biases may not be restricted only to social learning but it may also be present in other areas of social cognition research. Applying an equivalent analysis to cooperative problemsolving shows that here too both biases are present. Firstly, empirical studies on cooperative problem-solving were primarily conducted with social species and species that exhibit cooperative behaviours in the wild. Secondly, the assumption that cooperative problem-solving relies on a distinctly social cognitive ability can, at least implicitly, be observed throughout the literature. This may be the result of confounding different components of the cognitive process involved in cooperation: what information is required to successfully cooperate and how this information is acquired. While the former needs to involve information about another individual, there is no indication that the latter is required to differ from any known, domain-general cognitive mechanism. These two biases make it difficult to systematically test whether and how cooperation differs between species, and as such impede investigations into the evolution of cooperative problemsolving.
\end{abstract}

Keywords: evolution, social cognition, cooperation, cooperative problem-solving, learning, animals

Primljeno: 28. 2. 2020. 
